JAMP: Jurnal Adminitrasi dan Manajemen Pendidikan

Volume 5 Nomor 1 Maret 2022, Hal : 46- 52

Tersedia Online di http://journal2.um.ac.id/index.php/jamp/

ISSN 2615-8574 (online)

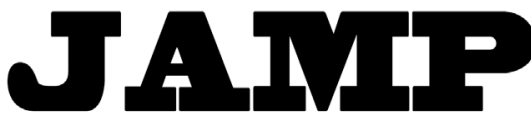

JURNAL ADMINISTRASI DAN MANAJEMEN PENDIDIKAN

\title{
PERSPEKTIF SISWA DAN GURU DALAM PELAKSANAAN AKM (ASESMEN KOMPETENSI MINIMUM) PADA MATA PELAJARAN KIMIA
}

\author{
Deni Ainur Rokhim ${ }^{1,2}$, Frida Kristining Tyas ${ }^{1}$, Sri Rahayu ${ }^{1}$, Habiddin ${ }^{1}$ \\ ${ }^{1}$ Pendidikan Kimia, FMIPA, Universitas Negeri Malang \\ Jl. Semarang No.5 Malang \\ ${ }^{2}$ SMAN 3 Sidoarjo \\ Jl. Dr. Wahidin No.130, Sekardangan, Kec. Sidoarjo, Kabupaten Sidoarjo \\ E-mail: deniainurrokhim@gmail.com.No.HP 083857257301
}

\begin{abstract}
Abstrak: Asesmen Kompetensi Minimum (AKM) merupakan standar penilaian kompetensi siswa melalui penguasaan literasi membaca dan numerasi. Tujuan penelitian untuk mengetahui perspektif siswa dan guru kimia SMAN 3 Sidoarjo dalam pelaksanaan AKM terhadap mata pelajaran kimia. Penelitian ini dilakukan guna memperbaiki kualitas pembelajaran dan penilaian guru terhadap siswa. Metode yang digunakan adalah penelitian studi kasus dengan pendekatan deskriptif kualitatif. Wawancara terhadap 10 responden siswa dan 3 responden guru melalui Google meet. Hasil wawancara dianalisis secara terpisah untuk setiap pertanyaan dan dilakukan analisis isi untuk menelaah data secara lebih rinci. Hasil AKM memberikan ruang bagi guru dan siswa untuk melakukan proses belajar mengajar yang lebih efesien sehingga meningkatkan pemahaman siswa terhadap suatu materi yang diberikan.
\end{abstract}

Keywords: Assesmen kompetensi minimum; pembelajaran kimia; numerasi; literasi

\begin{abstract}
Minimum Competency Assessment (AKM) is a standard for assessing student competence through mastering reading and numeracy literacy. The purpose of the study was to determine the perspectives of students and teachers of chemistry at SMAN 3 Sidoarjo in the implementation of AKM on chemistry subjects. This research was conducted to improve the quality of learning and teacher assessment of students. The method used is case study research with a qualitative descriptive approach. Interviews with 10 student respondents and 3 teacher respondents through Google meet. The results of the interviews were analyzed separately for each question and a content analysis was carried out to examine the data in more detail. The results of the AKM provide space for teachers and students to carry out a more efficient teaching and learning process so as to increase students' understanding of a given material.
\end{abstract}

Keywords: Minimum competency assessment; chemistry learning; numeracy; literacy

pendidikan perlu dipersiapkan dengan matang karena dalam pendidikan ada tujuan yang harus dicapai, yaitu untuk pengembangan potensi peserta didik agar menjadi kompeten, kreatif, mandiri dan berpikir kritis (Magara et al., 2021; Sari et al., 2019). Kualitas pendidikan terus bergerak dan berubah, dan spesifikasi dan kualifikasi juga terus meningkat. Oleh karena itu, prinsip kualitas dan kompetisi berbasis kompetensi perlu dibuka untuk semua (Rokhim et al., 2021; Tardian, 2019). Untuk mengevaluasi hasil dari mempersiapkan proses pendidikan, diperlukan alat ukur atau asesmen yang lebih objektif dalam mengukur siswa kompetensi (Aini, 2011). 
Penilaian (asesmen) hasil belajar merupakan langkah yang dilakukan untuk mengukur hasil belajar peserta didik. Penilaian hasil belajar oleh pendidik bertujuan untuk memantau dan mengevaluasi proses, kemajuan belajar, perbaikan hasil belajar peserta didik secara berkesinambungan, serta digunakan pemerintah untuk mengambil kebijakan dalam Pendidikan (Wilson, 2018). Penilaian memerlukan suatu instrumen (alat) yang digunakan agar hasil yang didapatkan objektif untuk mengukur hasil belajar siswa dengan tepat, baik berupa tes maupun tes (Anam et al., 2019; Rosita et al., 2020). Pada skala internasional, instrumen penilaian (asesmen) yang digunakan adalah PISA (Programme for International Student Assessment) dan TIMSS (Trend In International Mathematics And Science Study). Berdasarkan data OECD (2018), peringkat nilai PISA Indonesia tahun 2018 dalam tiga aspek yang dinilai yaitu membaca (peringkat 72 dari 77 negara), matematika (peringkat 72 dari 78 negara), dan sains (peringkat 70 dari 78 negara). Dalam 10-15 tahun terakhir, nilai Indonesia cenderung stagnan.

Sementara, nilai TIMSS Indonesia yang dilakukan pada peserta didik kelas 4 tahun 2015 berada pada peringkat ke 44 dari 49 negara pada aspek matematika dan peringkat ke 46 dari 49 negara pada aspek sains (Hadi, 2019; Siong \& Osman, 2018; Yuliandari \& Hadi, 2020). Selain TIMSS, hasil PISA sering dijadikan rujukan dalam pengambilan keputusan di berbagai negara termasuk di Indonesia. Pada tahun 2019, Menteri Pendidikan dan Kebudayaan menyampaikan secara resmi bahwa Ujian Nasional (UN) pada tahun 2021 akan dihapuskan dan digantikan dengan Asesmen Nasional (AN) dalam Program Merdeka Belajar. Ujian Nasional akan diganti dengan Asesmen Kompetensi Minimum (AKM) dan survei karakter pada tahun 2021 (Ulyah et al., 2021). Evaluasi tidak dilakukan sesuai dengan mata pelajaran atau penguasaan materi kurikulum yang telah diterapkan dalam ujian nasional, melainkan menginventarisasi keduanya kompetensi minimal siswa yaitu literasi dan numerasi (Purwati et al., 2021). Berdasarkan kompetensi minimal siswa yang harus dimiliki yaitu pada literasi dan numerasi. Salah satu mata pelajaran yang menuntut kemampuan tersebut adalah Kimia. Karakteristik mata pelajaran kimia juga sebagai materi utama dalam meningkatkan kompetensi literasi dan numerasi. Bagian tersebut terletak pada konten atau sub materi kimia yang menerapkan penyelesaian ilmiah (sains) dan berpikir kritis dalam menyelesaiakan suatu permasalahan. Konten tersebut bisa dalam bentuk teori atau bacaan yang dapat meningkatkan kemampuan literasi dan dalam bentuk hitungan seperti kemampuan stoikiometri guna meningkatkan kemampuan numerasinya. Pelaksanaan AKM ini berjalan dengan keterlibatan dua pelaku Pendidikan yaitu peserta didik dan guru. Peran serta guru dalam AKM ini memberikan pendampingan, pelatihan, dan pengajaran guna mempersiapkan pelaksanaan AKM, sedangkan siswa sebagai subjek uji untuk pengukuran tingkatan hasil belajar. Berdasarkan penelitian yang dilakukan oleh Ulyah et al., (2021) mengatakan bahwa peran penting keterlibatan semua stakeholder dalam pelaksanaan AKM terutama peran guru. Hal tersebut juga dialami Sekolah Menengah Atas Negeri 3 Sidoarjo yaitu dengan menerapkan pola pembelajaran yang berorientasi pada AKM serta merancang instrumen soal AKM sesuai kompetensi yang diminta dengan diintegrasikan pada mata pelajaran tertentu seperti halnya Kimia.

Berdasarkan latar belakang di atas, tulisan ini memberikan gambaran perspektif siswa dan guru kimia SMAN 3 Sidoarjo dalam pelaksanaan AKM pada mata pelajaran kimia. Hal ini perlu dilakukan penelitian guna memperbaiki kualitas pembelajaran dan penilaian kimia sebagai upaya sumbangsih proses dalam program AKM.

\section{METODE}

Penelitian ini menggunakan metode penelitian studi kasus dengan pendekatan deskriptif kualitatif. Penelitian survey adalah penelitian yang melibatkan sekelompok individu untuk menjawab sejumlah pertanyaan dalam instrumen, baik melalui pertanyaan wawancara, kuesioner, maupun tes (Rokhim et al., 2020; Sugiyono, 2017). Langkah penelitian studi kasus yang dilakukan terdiri dari 1) menentukan dan menjabarkan pertanyaan penelitian, 2) memilih dan menentukan disain dan instrumen penelitian, 3) menentukan tehnik pengumpulan data dan melakukan kegiatan pengumpulan data, 4) membuat analisa data, 5) dan mempersiapkan laporan akhir penelitian. 
Data yang diperoleh dari penelitian ini adalah data kualitatif. Data kualitatif diperoleh dari perspektif siswa dan guru dalam menjawab pertanyaan. Prosedur pengumpulan data dilakukan dengan menggunakan google form untuk responden siswa dalam mengetahui data umum siswa terkait pengetahuan AKM sebagai populasi penelitian. Data tersebut kemudian digunakan sebagai dasar untuk pemilihan 10 responden yang mewakili populasi. 10 responden kemudian dilakukan pengambilan data lanjutan melalui wawancara google meet. Sedangkan untuk responden guru dilakukan kepada guru kimia di sekolah sebanyak 3 guru dimana proses pengumpulan data juga melalui wawancara google meet. Analisis data penelitian dilakukan secara terpisah untuk setiap pertanyaan dan dalam proses ini dilakukan analisis isi untuk menelaah data secara lebih rinci. Teknik statistik deskriptif digunakan untuk menganalisis hasil penelitian tanpa digunakan untuk membuat kesimpulan yang lebih luas atau generalisasi (Muhadjir, 2000). Berikut pertanyaan yang diberikan pada siswa dan guru pada wawancara:

Tabel 1. Daftar Pertanyaan Siswa dan Guru

\begin{tabular}{|c|c|c|}
\hline & Pertanyaan Siswa & Pertanyaan Guru \\
\hline 1 & $\begin{array}{l}\text { Apakah Siswa mengetahui tentang AKM } \\
\text { (Assessment Kompetensi Minimum)? Tidak }\end{array}$ & $\begin{array}{l}\text { Apakah Bapak/Ibu mengetahui tentang AKM } \\
\text { (Assessment Kompetensi Minimum) }\end{array}$ \\
\hline 2 & $\begin{array}{l}\text { Seberapa dalam pengetahuan Siswa } \\
\text { mengenai AKM? }\end{array}$ & $\begin{array}{l}\text { Seberapa dalam pengetahuan Bapak/Ibu } \\
\text { mengenai AKM? }\end{array}$ \\
\hline 3 & $\begin{array}{l}\text { Darimana Siswa mendapatkan informasi } \\
\text { mengenai AKM? }\end{array}$ & $\begin{array}{l}\text { Darimana Bapak/Ibu mendapatkan informasi } \\
\text { mengenai AKM? }\end{array}$ \\
\hline 4 & $\begin{array}{l}\text { Apakah Siswa sudah menggunakan AKM } \\
\text { dalam proses pembelajaran kimia? }\end{array}$ & $\begin{array}{l}\text { Menurut Bapak/Ibu, bagaimana karakteristik } \\
\text { Instrumen AKM dalam mata pelajaran kimia? }\end{array}$ \\
\hline 5 & $\begin{array}{l}\text { Apakah Siswa sudah menerapkan AKM pada } \\
\text { penilaian sumatif dan formatif mata pelajaran } \\
\text { kimia? }\end{array}$ & $\begin{array}{l}\text { Apakah Bapak/Ibu sudah menerapkan AKM } \\
\text { dalam proses penilaian pelajaran kimia? }\end{array}$ \\
\hline 6 & $\begin{array}{l}\text { Bagaimana instrument AKM dalam kaitannya } \\
\text { dalam pross pembelajaran kimia? }\end{array}$ & $\begin{array}{l}\text { Apakah Bapak/Ibu sudah menerapkan AKM } \\
\text { pada penilaian sumatif dan formatif mata } \\
\text { pelajaran kimia? }\end{array}$ \\
\hline 7 & - & $\begin{array}{l}\text { Apakah semua materi kimia dapat dibuat } \\
\text { menjadi soal tipe AKM? }\end{array}$ \\
\hline 8 & - & $\begin{array}{l}\text { Bagaimana instrument AKM dalam kaitannya } \\
\text { dalam pross pembelajaran kimia? }\end{array}$ \\
\hline
\end{tabular}

\section{HASIL DAN PEMBAHASAN}

Penelitian ini dilakukan secara kualitatif dengan memberikan pertanyaan pada siswa dan guru. Tujuan dari pertanyaan wawancara, yaitu untuk menggali perspektif AKM dari siswa dan guru SMAN 3 Sidoarjo. Populasi yang terbentuk sebagai data umum siswa terkait pengetahuan AKM melalui Google form adalah 150 siswa. Data tersebut kemudian digunakan sebagai dasar untuk pemilihan 10 responden yang mewakili populasi. Hasil pelaksanaan wawancara disajikan pada Tabel 2 untuk siswa dan Tabel 3 untuk jawaban dari guru.

Tabel 2. Hasil Pelaksanaan Wawancara Siswa

\begin{tabular}{cl}
\hline Pertanyaan & \multicolumn{1}{c}{ Hasil Jawaban } \\
\hline 1 & Semua siswa telah mengetahui mengenai AKM \\
2 & 5 siswa memiliki pemahaman sangat baik \\
& 4 siswa memiliki pemahaman baik \\
& 1 siswa memiliki pemahaman sedang \\
3 & $\begin{array}{l}\text { Dari sekolah dengan adanya pelatihan yang dilaksanakan kurang lebih selama 1 bulan } \\
\text { dan tes AKM selama 2 hari }\end{array}$
\end{tabular}




\begin{tabular}{cl}
\hline Pertanyaan & \multicolumn{1}{c}{ Hasil Jawaban } \\
\hline 4 & $\begin{array}{l}\text { 9 siswa telah menggunakan AKM dalam proses pembelajaran kimia, 1 siswa } \\
\text { menyatakan sudah mengetahui literasi dan numerasi namun belum mencoba pada } \\
\text { pelajaran kimia }\end{array}$ \\
& $\begin{array}{l}9 \text { siswa telah menerapkan AKM pada penilaian sumatif dan formatif mata pelajaran } \\
\text { kimia, 1 siswa menyatakan terdapat beberapa soal kimia dengan AKM namun } \\
\text { kebanyakan langsung pada inti soal }\end{array}$ \\
& $\begin{array}{l}\text { Sangat berkaitan, AKM membantu memberikan pemahaman dengan literasi dan } \\
\text { numerasi, diperlukan dalam menyelesaikan masalah, dan memberikan motivasi } \\
\text { belajar. }\end{array}$ \\
\hline
\end{tabular}

Tabel 2 menunjukkan hasil pelaksanaan wawancara pada 10 siswa sebagai sampel. Pernyataan kesepuluh siswa tersebut telah mewakili populasi yang ada. AKM dianggap efektif dalam memberikan pemahaman materi kimia melalui literasi membaca dan numerasi.

Tabel 3. Hasil Pelaksanaan Wawancara Siswa

\begin{tabular}{|c|c|}
\hline Pertanyaan & Hasil Jawaban \\
\hline 1 & Semua guru telah mengetahui mengenai AKM \\
\hline 2 & $\begin{array}{l}\text { Sangat baik, guru memahami AKM sebagai sistem penilaian kemampuan minimum } \\
\text { pada hasil kognitif belajar dan mengajar yang lebih menitik beratkan pada sistem } \\
\text { literasi dan numerasi }\end{array}$ \\
\hline 3 & $\begin{array}{l}\text { Semua guru mendapatkan informasi mengenai AKM dari kepala sekolah kemudian } \\
\text { dilanjutkan dengan sosialisasi melalui media sosial dan cetak serta pelatihan yang } \\
\text { dilaksanakan dari pengawas, akademisi pemerhati pendidikan dan kementrian }\end{array}$ \\
\hline 4 & $\begin{array}{l}\text { Karakteristik Instrumen AKM dalam mata pelajaran kimia adalah kimia sebagai } \\
\text { konten yang dapat ditarik dalam literasi pada materi yang berbasis teoritik dan } \\
\text { numerik yang berbasis hitungan sebagai ujung tombak untuk meningkatkan } \\
\text { kemampuan siswa }\end{array}$ \\
\hline 5 & Semua guru telah sudah menerapkan AKM dalam proses penilaian pelajaran kimia \\
\hline 6 & $\begin{array}{l}\text { Semua guru telah sudah menerapkan AKM pada penilaian sumatif dan formatif mata } \\
\text { pelajaran kimia }\end{array}$ \\
\hline 7 & $\begin{array}{l}\text { Semua guru menjawab semua materi kimia dapat dibuat menjadi soal tipa AKM } \\
\text { karena kimia terdiri dari bacaan dan hitungan sesuai dengan AKM dapat diterapkan } \\
\text { secara literasi dan numerasi }\end{array}$ \\
\hline 8 & $\begin{array}{l}\text { Semua guru menjawab sangat berkaitan, karena kimia adalah pelajaran yang } \\
\text { paling susah meliputi menghapal dan menghitung, sehingga proses penilaian teori } \\
\text { diarahkan dalam literasi dan pada hitungan dengan numerasi. AKM membantu } \\
\text { meningkatkan kemampuan literasi dan numerasi siswa. }\end{array}$ \\
\hline
\end{tabular}

Tabel 3 menunjukkan hasil pelaksanaan wawancara pada 3 guru kimia. pernyataan ketiga guru memberikan pernyataan secara rinci pelaksanaan AKM di sekolah.

\section{Perspektif Pelaksanaan AKM dalam Mapel Kimia dari Sudut Pandang Siswa}

AKM (Asesmen Kompetensi Minimum) merupakan jenis penilaian yang dapat mengukur kemampuan pemecahan masalah siswa melalui literasi dan numerasi sehingga diharapkan siswa mampu mengembangkan kapasitas dirinya (Hasanah et al., 2021). Literasi numerasi berarti pengetahuan dan kecakapan untuk memperoleh, menafsirkan, dan mengomunikasikan berbagai macam angka dan simbol serta menganalisis informasi yang ditampilkan untuk memecahkan suatu masalah. Pelaksanaan AKM bertujuan untuk: (1) mendeskripsikan keberhasilan penguasaan kompetensi siswa, (2) mendeskripsikan keberhasilan proses pembelajaran, (3) menentukan tindak lanjut hasil penilaian, (4) sebagai bentuk pertanggungjawaban pihak sekolah kepada orang tua dan masyarakat, dan (5) sebagai bahan perbaikan proses kegiatan belajar mengajar (Rohim et al., 2021) 
Berdasarkan Tabel 2 pada pertanyaan 1,2 dan 3 hasil pelaksanaan wawancara didapatkan pandangan siswa mengenai pengetahuannya terhadap AKM. Seluruh siswa menyatakan bahwa telah mengetahui AKM. AKM merupakan program dari Pemerintah untuk mempersiapkan PISA (Program Penilaian Pelajar Internasional), maka dari itu Pemerintah melakukan pelatihan terhadap guru dan siswa di seluruh Indonesia sebagai upaya untuk meningkatkan skor PISA. Pelaksanaan pelatihan pada siswa dilaksanakan selama satu bulan dengan diakhiri ujian berbasis soal AKM selama dua hari. Melalui pelatihan ini siswa diharapkan memiliki pengetahuan yang baik mengenai AKM dan mampu menerapkannya sehingga dapat meningkatkan proses pemahaman terhadap suatu materi pelajaran. Fakta bahwa siswa memiliki pengetahuan mengenai AKM tersebut diperkuat dengan hasil wawancara siswa. Berikut cuplikan wawancara pada pertanyaan 1,2 , dan 3 :

$\mathrm{S}_{1}$ : "ya saya telah mengetahui AKM dari sekolah"

$\mathrm{S}_{2}$ : "mengetahui AKM dari pelatihan yang diadakan sekolah"

$\mathrm{S}_{3}$ : "ya dengan adanya AKM dapat mengasah tingkat pemahaman siswa"

$\mathrm{S}_{7}$ : "ya ssaya mengetahui AKM"

$\mathrm{S}_{8}$ : "ya, AKM merupakan soal-soal yang menonjolkan literasi"

Cuplikan wawancara tersebut selaras dengan pernyataan Rokhim et al., (2021) bahwa AKM meliputi literasi membaca dan numerasi hitungan untuk meningkatkan mutu pendidikan Indonesia. Berdasarkan hasil pelaksanaan wawancara 5 siswa memiliki pemahaman yang sangat baik mengenai AKM, 4 siswa memiliki pemahaman yang baik, dan 1 siswa memiliki pemahaman sedang.

Pertanyaan 4 dan 5 pada pelaksanaan wawancara didapatkan hasil mengenai penerapan AKM dalam pembelajaran terutama pada pelajaran kimia. Pelatihan AKM memberikan siswa aktif dalam belajar serta meningkatkan pemahaman siswa terhadap materi yang disampaikan. Fakta bahwa siswa telah menerapkan AKM pada pembelajaran kimia diperkuat dengan cuplikan wawancara berikut:

$S_{I}$ : "Ya, saya telah menerapkan AKM pada pembelajaran kimia. Pada penilaian formatif maupun sumatif"

$S_{2}$ : "Ya, sudah menerapkan AKM, dan PTS kisi-kisinya sudah sesuai dengan AKM"

$S_{I}$ : "Ya, sudah menerapkan"

Sembilan siswa menyatakan telah menerapkan AKM dalam pembelajaran kimia, ujian sumatif, dan formatif. 1 siswa menyatakan bahwa belum melaksanakan AKM dalam pembelajaran kimia serta pada ujian sumatif, dan formatif hanya beberapa soal saja. Hal ini dimungkinkan karena media pembelajaran belum bisa didapatkan siswa tersebut sehingga hanya mengandalkan penjelasan dari guru.

Pertanyaan 6 memberikan hasil pandangan siswa mengenai keterkaitannya AKM dengan mata pelajaran kimia. Berikut hasil cuplikan wawancara dengan siswa:

$S_{2}$ : “ Sangat berkaitan AKM dengan pelajaran kimia, dari pretest dan materi yang ada dilakukan dengan kisi-kisi AKM"

$S_{5}:$ "Berkaitan siswa dituntut untuk belajar secara mandiri dan guru memberikan soal sesuai materi"

$S_{6}:$ "Sangat berkaitan AKM melatih literasi dan numrasi"

$S_{8}:$ " Berkaitan AKM menuntut siswa untuk dapat belajar dengan mandiri dan membantu pemahaman literasi untuk menjawab soal"

Cuplikan wawancara tersebut menunjukkan kimia sebagai konten berisi materi teori yang dapat dikaitkan dengan literasi dan berisi materi hitungan yang dikaitkan dengan numerasi. Dengan kemampuan literasi dan numerasi siswa mampu melihat hubungan kimia dengan kehidupan sehari-hari, memiliki kemampuan dalam pemecahan soal, dan meningkatkan pemahaman siswa.

\section{Perspektif Pelaksanaan AKM dalam Mapel Kimia dari Sudut Pandang Guru}

Berdasarkan Tabel 3 pada pertanyaan 1,2 dan 3 hasil pelaksanaan wawancara didapatkan pandangan siswa mengenai pengetahuannya terhadap AKM. Seluruh guru menyatakan telah mengetahui AKM. AKM yang merupakan program pemerintah diawali dengan diselenggarakannya sosialisasi pada media sosial dan media cetak kemudian dilanjutkan dengan pelatihan serta disediakannya wadah informasi bagi guru berupa web yaitu Pusmenjar. Melalui upaya-upaya tersebut diharapkan guru dapat memahami 
dan menerapkan AKM pada pembelajarannya kepada siswa. Fakta bahwa guru memiliki pengetahuan mengenai AKM diperkuat dengan cuplikan wawancara berikut:

$G_{I}:$ "AKM merupakan sistem penilaian kompetensi siswa sebagai hasil kognitif belajar dan mengajar. AKM dilakukan oleh pengawas sekolah setiap bulan"

$G_{2}:$ "AKM merupakan proses penilaian yang diseragamkan se-Indonesia mengenai batas minimum untuk meningkatkan pemahaman literasi dan numerasi siswa. Terdapat pusmenjar yang memberikan segala informasi $A K M$ "

$G_{3}:$ "AKM merupakan merupakan sistem penilaian minimum yang menitik beratkan pada sistem literasi dan numerasi. Pelatihan mengenai AKM diselenggarakan oleh sekolah"

Cuplikan wawancara di atas sesuai dengan pernyataan Rokhim et al., (2021) bahwa AKM meliputi literasi membaca dan numerasi hitungan untuk meningkatkan mutu pendidikan Indonesia. Dalam konteks pengetahuan AKM, responden yang diwawancari memberikan pengetahuan yang baik, hal tersebut ditunjukkan dalam penjelasan yang detail terkait AKM dan menjelaskan informasi-inforasi penting dalam pelaksanaan AKM terutama pada mapel Kimia.

Pertanyaan 4, 7, dan 8 responden guru memberikan gambaran karakteristik instrumen AKM dalam mata pelajaran kimia. Mata pelajaran Kimia merupakan salah satu mata pelajaran eksakta yang menjadi konten dalam instrumen AKM. Konten pada instrumen AKM meliputi literasi dan numerasi. Kimia sebagai konten artinya dapat ditarik dalam literasi pada materi yang berbasis literasi (teoritik) dan numerasi yang berbasis hitungan. Seluruh materi dalam pelajaran kimia dapat diterapkan dan diaplikasikan dalam AKM. Materi yang berbasis teoritik seperti kimia hijau, struktur atom, ikatan kimia, hidrokarbon dan koloid. Materi yang berbasis numerik seperti termodinamika, laju reaksi, kesetimbangan kimia, stoikiometri dan asam basa. AKM diharapkan dapat menjadi ujung tombak untuk meningkatkan kemampuan siswa. Kemampuan siswa yang diharapkan dalam pelaksanaan AKM pada mapel Kimia yaitu kemampuan berliterasi, kemampuan bernumerasi, dan kemampuan berpikir kritis. Capain kemampuan tersebut sesuai dengan penelitian Rohim et al., (2021) yang menjelaskan pelaksanaan Asesmen Kompetensi Minimum (AKM) diharapkan dapat meningkatkan kemampuan literasi numerasi siswa di sekolah dasar, dan penelitian Yuliandari \& Hadi (2020) mengatakan instrumen AKM berdampak terhadap peningkatan potensi intelektual pada aspek kognitif, emosional, fisik, sosial dan estetika sebagai aspek afektif.

Pertanyaan 5 dan 6 pada pelaksanaan wawancara didapatkan hasil mengenai penerapan AKM dalam proses pembelajaran oleh guru. Seluruh respoonden guru menyatakan bahwa AKM telah diterapkan pada pembelajaran kimia serta pelaksanaan ujian formatif dan sumatif. Melalui AKM guru dapat membuat soal secara bervariasi sehingga siswa lebih mampu dalam pemahaman materi. Variasi soal tersebut juga memberikan guru pandangan sejauh mana siswa memiliki kedalaman pemahaman materi. Variasi soal meliputi soal pilihan ganda satu jawaban, pilihan ganda lebih dari satu jawaban, soal menjodohkan, soal benar salah, soal uraian singkat dan uraian panjang. Instrumen AKM sangat berkaitan dengan pembelajaran kimia, hal ini selaras dengan seluruh pernyataan guru. Kimia merupakan salah satu mata pelajaran yang paling sulit karena mengandung banyak konsep teori dan hitungan, melalui instrumen AKM ini sangat membantu guru menyampaikan materi dan mempermudah siswa dalam proses pemahamannya. AKM membangun kontruktivisme dalam meningkatkan kemampuan literasi dan numerasi siswa.

\section{SIMPULAN DAN SARAN}

\section{Simpulan}

Asesmen Kompetensi Minimum (AKM) merupakan standar penilaian kompetensi siswa yang berfokus pada penguasaan literasi dan numerasi. AKM memberikan ruang bagi guru dan siswa untuk melakukan proses belajar mengajar yang lebih efesien sehingga meningkatkan pemahaman siswa terhadap suatu materi yang diberikan. Rancangan AKM ditujukan untuk memperbaiki kualitas pendidikan secara menyeluruh. 


\section{Saran}

Penelitian selanjutnya diharapkan dapat melakukan studi kasus dalam ruang lingkup yang lebih besar. AKM ditujukan untuk memperbaiki kualitas pendidikan secara menyeluruh sehingga perlu diketahui ketersebaran hasil penerapannya.

\section{DAFTAR RUJUKAN}

Aini, F. N. (2011). Identifikasi Pemahaman Konseptual Siswa Kelas XII IPA-1 Dan XII IPA-2 Sma Negeri 6 Malang Tahun Ajaran 2010/2011 Pada Materi Aplikasi Reaksi Redoks Dan Elektrokimia Dalam Kehidupan SehariHari [Universitas Negeri Malang]. Http://Karya-Ilmiah.Um.Ac.Id/Index.Php/Kimia/Article/View/12629

Anam, R. S., Widodo, A., Sopandi, W., \& Wu, H. K. (2019). Developing A Five-Tier Diagnostic Test To Identify Students' Misconceptions In Science: An Example Of The Heat Transfer Concepts. Elementary Education Online, 18(3), 1014-1029. Https://Doi.Org/10.17051/Ilkonline.2019.609690

Hadi, S. (2019). Timss Indonesia ( Trends In International Mathematics And Science Study ). Prosiding Seminar Nasional \& Call For Papers Program Studi Magister Pendidikan Matematika Universitas Siliwangi, 562569.

Hasanah, U., Edwita, \& Januar, A. (2021). Pendampingan Guru Mengembangkan Assesment Kompetensi Minimum ( Akm ) Berorientasi Pisa Untuk. Jurnal Abadimas Adi Buana, 5(01), 90-99.

Magara, E., Copriady, J., \& Linda, R. (2021). Karakteristik Instrumen Asesmen Kamampuan Berpikir Kreatif Siswa Pada Materi Hidrokarbon. Prosiding Seminar Nasional Penelitian Dan Pengabdian 2021, 1, $76-88$.

Muhadjir, N. (2000). Metode Penelitian Kualitatif. Yogyakarta: Rake Sarasin.

Purwati, P. D., Faiz, A., Widiyatmoko, A., \& Maryatul, S. (2021). Asesmen Kompentensi Minimum (Akm) Kelas Jenjang Sekolah Dasar Sarana Pemacu Peningkatan Literasi Peserta Didik. 19(1), 13-24.

Rohim, D. C., Rahmawati, S., \& Ganestri, I. D. (2021). Konsep Asesmen Kompetensi Minimum Meningkatkan Kemampuan Literasi Numerasi Sekolah Dasar Untuk Siswa. Jurnal Varidika, 33(1), 54-62. Https://Doi. Org/10.23917/Varidika.V33i1.14993

Rokhim, D. A., Rahayu, B. N., Alfiah, L. N., Peni, R., Wahyudi, B., Wahyudi, A., Widarti, H. R., \& Malang, U. N. (2021). Analisis Kesiapan Peserta Didik Dan Guru Pada Asesmen Nasional (Asesmen Kompetensi Minimum , Survey Karakter, Dan Survey Lingkungan Belajar ). Jurnal Administrasi Dan Manajemen Pendidikan, 4, 61-71.

Rokhim, D. A., Wulandari, I. A. I., \& Alifah, L. N. (2020). Analisis Dampak Anjuran Pemerintah Terhadap Belajar Di Rumah Bagi Pelaku Pendidikan. Jamp: Jurnal Adminitrasi Dan Manajemen Pendidikan, 3(3), $216-233$.

Rosita, I., Liliawati, W., \& Samsudin, A. (2020). Pengembangan Instrumen Five-Tier Newton's Laws Test (5tnlt) Untuk Mengidentifikasi Miskonsepsi Dan Penyebab Miskonsepsi Siswa. Jurnal Pendidikan Fisika Dan Teknologi, 6(2), 297. Https://Doi.Org/10.29303/Jpft.V6i2.2018

Sari, K., Sujarwanta, A., \& Santoso, H. (2019). Pengembangan Lembar Kegiatan Peserta Didik (Lkpd) Pembelajaran Biologi Berbasis Keterampilan Berpikir Kritis Pada. Jurnal Lentera Pendidikan Pusat Penelitian Lppm Um Metro, 4(1), 63-72.

Siong, W. W., \& Osman, K. (2018). Pembelajaran Berasaskan Permainan Dalam Pendidikan Stem Dan Penguasaan Kemahiran Abad Ke-21. Politeknik \& Kolej Komuniti Journal Of Social Sciences And Humanities, 3, 1282875.

Sugiyono. (2017). Metode Penelitian Kuantitatif, Kualitatif, Dan R\&D.

Tardian, A. (2019). Manajemen Strategik Mutu Sekolah. Jurnal Kependidikan, 7(2), 192-203.

Ulyah, S. M., Ana, E., \& Sholihah, N. (2021). Improving The Competency Of High School Teachers In Understanding And Designing Questions Based On Minimum Competency Assessment In Babat Lamongan District Department Of Mathematics , Airlangga University, Surabaya Statistics Study Program , Airlangga Un. 6(1), 55-64.

Wilson, M. (2018). Making Measurement Important For Education : The Crucial Role. 37(1), 5-20.

Yuliandari, R. N., \& Hadi, S. (2020). Implikasi Asesmen Kompetensi Minimum Dan Survei Karakter Terhadap Pengelolaan Pembelajaran SD. 